\title{
COMMUNIO-KOINONIA \\ MENURUT VISI PAROKI KATEDRAL KRISTUS RAJA DALAM PERTEMUAN AKSI PUASA PEMBANGUNAN
}

\author{
Dhimas Martin Yuniar
}

\begin{abstract}
:
Diocese of Purwokerto idealizes a community of God's Kingdom Church, which by then becomes a together movement of the Catholics in Diocese of Purwokerto. Each parish, including Parish Cathedral Kristus Raja of Purwokerto, makes a vision which is appropriate with the need and situation of the Catholics in this parish. The event of Aksi Puasa Pembangunan, becomes a method that is really suitable with the efforts of this Church in presenting a community which is communious internally and externally as well.

In this research, the intention of APP, is not fully caught and comprehended by the Catholic people of Cathedral Kristus Raja of Purwokerto. Therefore APP meeting have not really helped the Cathedral to build its community's identity.

To make it more effective and efficient in presenting the ideal community, Cathedral Kristus Raja of Purwokerto needs to make some pastoral steps. It is hoped that APP can become a program to build a community which is holy, autonomic, mature, dynamic, growing in true brotherhood and becoming the light and salt of world.
\end{abstract}

\section{Kata-kata Kunci:}

Communio, Koinonia, Aksi Puasa Pembangunan, Prapaskah, Paroki Katedral Kristus Raja Purwokerto.

\section{PENDAHULUAN}

\subsection{Latar Belakang}

Communio merupakan salah satu aspek kehidupan Gereja. Communio berasal dari kata Latin yang memiliki makna assosiation, participation, status of being common, the fact of sharing the same faith. ${ }^{1}$ Kata Latin itu untuk menerjemahkan kata dalam bahasa Yunani yaitu koinonia, yang memiliki akar kata dasar berbagi sesuatu hal dengan seseorang. ${ }^{2}$ Dalam konteks Kristiani, communion diterjemahkan dengan "a relation between individual christians or christian communities resulting from their common participation in one and the same reality". "Melalui baptis, orang dimasukkan ke dalam communio eklesial, yang menyatukan mereka dengan seluruh umat beriman. ${ }^{4}$ Kesatuan dengan Allah yang menjadi dasarnya.
Communio atau koinônia itu memiliki beberapa aspek atau cakupan dalam kitab suci yaitu menyangkut komunitas (Kor 13:13, 1 Yoh 1:3), semangat berbagi (2Kor 9:13), tanda/ bentuk dari suatu persahabatan (Kis 2:42), dan participation in collection or in common good (2Kor 8:4). ${ }^{5}$

Pemahaman akan Gereja sebagai communio didasarkan pula pada konsep Gereja sebagai Tubuh Kristus dalam surat St. Paulus. Ia menekankan kesatuan, saling memperhatikan, dan saling membutuhkan antar umat beriman. Gereja adalah sebuah paguyuban (communio) umat beriman yang berciri spiritual batiniah yang kemudian diungkapkan melalui ikatan-ikatan yang kelihatan. Bentuk paguyuban-paguyuban itu mengandaikan juga terdiri dari relasi-relasi manusiawi.

Gereja sebagai sebuah communio juga kemudian diwujudkan secara khusus sesuai 
dengan ciri khas di mana Gereja itu hidup. Di Keuskupan Purwokerto, dalam masa penggembalaan Mgr Julianus Sunarka, SJ, communio diterjemahkan sebagai sebuah paguyuban yang menjadi tanda kehadiran Kerajaan Allah. Dalam visinya, bapa Uskup menekankan ciri pelopor Kerajaan Allah. Gereja Keuskupan Purwokerto sebagai sebuah komunitas memiliki tugas untuk menghadirkan Kerajaan Allah di dalam komunitas mereka sekaligus berhadapan dengan komunitas lainnya. Di dalam visi itu ada sisi ke dalam dan sisi ke luar. Demikian pula bapa Uskup menekankan kerjasama dengan mereka semua yang berkehendak baik dalam menghadirkan Kerajaan Allah.

Bentuk communion atau koinônia yang khusus/ khas bagi Keuskupan Purwokerto itu kemudian diterjemahkan oleh Paroki Katedral Kristus Raja (PKKR) Purwokerto melalui visi misinya yang disesuaikan dengan situasi dasar wilayah paroki ini. Sebagai Gereja lokal, PKKR menerjemahkan cita-cita communio itu melalui visi misi yang bertitik tolak pada jati diri PKKR. Tahun 1998, PKKR mulai menggulati visi "Paroki Katedral adalah persekutuan umat beriman yang misioner, tertata rapi, mandiri dan berdaya tahan atas dasar cinta kasih Kristus yang memanggil dan mengutus, berkembang dalam persaudaraan sejati, sehingga menjadi terang dan garam di tengah masyarakat". ${ }^{6}$ Dari visi tersebut, ternyata communio secara khusus diterjemahkan dengan kata persekutuan. Namun persekutuan memiliki ciri-ciri khusus yang menjadi jati diri sekaligus cita-cita PKKR. Persekutuan tersebut memiliki empat ciri yaitu misioner, tertata rapi, mandiri dan berdaya tahan. Dari beberapa misi itu dapat ditemukan empat unsur yang menjadi idealisasi communio yang dicita-citakan PKKR pada tahun 1998 sampai dengan 2007, yaitu tanggungjawab bersama, komunikasi, kerjasama, dan keterlibatan aktif dalam Gereja dan masyarakat.

Pada tahun 2007, perjalanan membangun persekutuan yang misioner, tertata rapi, mandiri dan berdaya tahan yang berisikan tanggungjawab bersama, komunikasi, kerjasama, dan keterlibatan aktif itu dievaluasi melalui penelitian yang dilakukan oleh Tim Visi Misi PKKR. ${ }^{7}$ Penelitian itu menyatakan bahwa hanya separuh umat yang mengatakan sudah ada keterlibatan dan kerjasama antara warga lingkungan dalam kegiatan yang diadakan di lingkungannya. Sedangkan separuh yang lain belum dan kurang mengalami kerjasama dan keterlibatan tersebut. Lebih dari sepertiga dari responden mengalami kurangnya keterlibatan dan kerjasama anggota atau warga lingkungan/ paroki dalam kegiatan-kegiatan yang diadakan oleh lingkungan atau paroki. Hanya separuh yang mengatakan keterlibatan dan kerjasama itu sudah tercapai. Bahkan jalinan persaudaraan di dalam lingkungan sungguh-sungguh dialami hanya oleh kurang dari separuh umat. Dengan data itu, nampak bahwa konsep persaudaraan sejati yang berisikan tanggungjawab bersama, kerjasama, dan keterlibatan aktif umat belum sepenuhnya terwujud.

Oleh karena itu pada tahun 2007, saat penyusunan visi-misi paroki yang baru untuk tahun 2008-2017, meski ada perubahan, PKKR tetap mencantumkan beberapa gagasan communio visi sebelumnya. Beberapa unsur gagasan communio PKKR dalam visi 2008-2017 adalah persekutuan yang kudus, dewasa, mandiri, dinamis, berkembang dalam persaudaraan sejati dan menjadi garam dan terang bagi masyarakat. Visi tersebut ditempuh dengan lima misi yaitu meningkatkan kualitas kehidupan rohani umat, kedewasaan umat, keterlibatan aktif umat dalam hidup menggereja dan memasyarakat, kesadaran umat terhadap kemajemukan dan kesediaan untuk menerima perbedaan, dan mengembangkan cara-cara hidup alternatif dalam semua aspeknya. ${ }^{8}$ Semua itu dicapai dengan menghayati spiritualitas Kristus Raja Semesta Alam, pelindung PKKR.

Unsur-unsur communion tersebut merupakan unsur konkret dari communio yang dicanangkan oleh keuskupan. Kerajaan Allah yang begitu luas maknanya, di PKKR diterjemahkan dengan sebuah persekutuan yang kudus, dewasa, mandiri, dinamis, berkembang dalam persaudaraan sejati dan menjadi garam dan terang bagi masyarakat.

\subsection{Rumusan Masalah}

Gereja Kerajaan Allah yang dicanangkan Keuskupan Purwokerto itu secara teoritis telah dijawab oleh PKKR melalui visinya yaitu persekutuan yang kudus, dewasa, mandiri, dinamis, berkembang dalam persaudaraan sejati dan menjadi garam dan terang bagi masyarakat. Kelima hal itu adalah penekanan dari visi keuskupan sebagai kebersamaan dalam mengambil bagian dalam gerak keuskupan. 
Persekutuan menjadi sumber pokok dalam mengembangkan Kerajaan Allah yang dicitacitakan Keuskupan Purwokerto.

Visi PKKR mulai digeluti sejak tahun 2008, namun apakah seluruh aspek persekutuan dalam tataran praktis sudah tergarap dengan baik khususnya melalui gerakan APP tahunan?

\subsection{Metode Penelitian}

Penelitian ini dilakukan dengan mengambil obyek penelitian di seluruh lingkungan di Paroki Katedral Kristus Raja Purwokerto. Jumlah keseluruhan lingkungan adalah 19 lingkungan yang tersebar di dalam kota Purwokerto. Total jumlah umat yang ada di 19 lingkungan adalah 1185 Kepala Keluarga atau mencapai 3998 jiwa. Responden diambil sejumlah $10 \%$ dari total jumlah kepala keluarga yaitu sejumlah 118 orang.

Pemilihan responden dilakukan dengan sistem proportional random sampling. ${ }^{9}$ Peneliti menyerahkan pemilihan responden kepada masing-masing ketua lingkungan atau orang yang paham mengenai lingkungan tersebut. Kemudian mereka memilih $10 \%$ dari jumlah Kepala Keluarga (sudah ditentukan) dengan variasi terhadap: jenis kelamin, usia, pekerjaan dan pendidikan. Keempat variasi ini menjadi dasar dalam variasi (proporsi) responden. Dalam hal variasi usia, pengambilan responden mengalami keterbatasan pilihan karena amat jarang sekali ada lingkungan yang dalam pertemuan APP lingkungan dihadiri oleh kaum muda (usia 14-35 tahun). Di samping itu, tingkat kehadiran warga lingkungan dalam pertemuan APP lingkungan juga sangat rendah. Sebagian besar lingkungan mengadakan pertemuan dalam satu kelompok yang dihadiri oleh 10 sampai dengan 30 orang. Sedangkan 3 lingkungan mengadakannya dengan membagi menjadi 2-4 kelompok yang masingmasing kelompok dihadiri 15-20 orang. Di samping itu ada satu lingkungan yang menurut beberapa sumber, tidak mengadakan pertemuan APP.

Penelitian ini dilakukan dengan metode kuantitatif. Penelitian ini menggunakan sebuah angket yang terdiri dari identitas diri dan 30 pertanyaan. Identitas diri itu meliputi nama responden, jenis kelamin, umur, pekerjaan, pendidikan, suku bangsa dan bentuk keterlibatan mereka dalam Gereja (tugas Gerejani). 30 pertanyaan itu terdiri dari 21 pertanyaan tertutup dan 9 pertanyaan terbuka. Dalam pengumpulan data, penulis dibantu oleh beberapa relawan. Para relawan mengenal situasi dan orang-orang yang biasa terlibat dalam pertemuan lingkungan atau hadir dalam pertemuan APP lingkungan. Para relawan ini bekerja sejak tanggal 21 Maret 2010 dan selesai seluruhnya pada tanggal 16 April 2010.

Dalam pembacaan dan analisis data penelitian ini digunakan basic variable kategori tingkat pendidikan. Variabel ini menjadi dasar karena variabel pendidikan merupakan variabel yang tidak mudah berubah, konsisten dan terukur dengan jelas. Artinya variabel ini dapat mempengaruhi cara pandang dan kemampuan seseorang untuk mamahami, mengerti, berefleksi dan menimbang sesuatu. Kategori pendidikan ini juga mempengaruhi posisi sosial seseorang di tengah masyarakat dan sesamanya. Dalam kategori pendidikan, responden terbagi dalam empat kategori. Kategori pendidikan ini ditetapkan berdasarkan tamatan yang dicapai oleh responden. Keempat kategori itu antara lain sebelum tamat SLTA yang meliputi tidak sekolah sampai tamatan SLTP, tamatan SLTA, Diploma (baik D1 sampai dengan D4), dan Sarjana yang meliputi Strata Satu dan seterusnya.

\subsection{Tujuan dan Manfaat}

Penelitian ini memiliki tujuan untuk memberdayakan dan meningkatkan kualitas pertemuan lingkungan APP Prapaskah terhadap usaha mencapai visi persekutuan yang diidealkan oleh Paroki Katedral Kristus Raja Purwokerto. Selain itu juga berusaha menemukan usulanusulan langkah pastoral untuk membangun aspek communio yang dicita-citakan oleh PKKR. Beberapa manfaat yang dapat diperoleh adalah:

a) Penelitian ini bisa menjadi bahan evaluasi pelaksanaan program kerja Dewan Pastoral Paroki periode 2007-2010 serta data bagi kebijakan-kebijakan pastoral Pastor Paroki Katedral Kristus Raja Purwokerto.

b) Bagi DPP, penelitian ini dapat menjadi bahan pertimbangan membuat program kerja dalam Masa Prapaskah.

c) Penelitian ini juga bisa menjadi data sekunder pelaksanaan pertemuan APP Prapaskah Lingkungan bagi Tim Katekese Dewan Pastoral Paroki Katedral Kristus Raja Purwokerto. 
d) Bagi Keuskupan Purwokerto, penelitian ini dapat membantu melihat dan mengevaluasi pelaksanaan visi keuskupan dalam menghadirkan Kerajaan Allah.

\section{LANDASAN TEORI}

Pertemuan APP Prapaskah Lingkungan diharapkan mampu membangun communio yang dicita-citakan umat Paroki Katedral Kristus Raja Purwokerto. Dengan semakin terlibat dalam kegiatan APP tahunan, aspek-aspek persekutuan yang dicita-citakan PKKR semakin terwujud.

\subsection{Communio dalam Visi PKKR}

Paroki Katedral Kristus Raja memiliki pemahaman yang khusus mengenai sebuah communio. Communio yang dicita-citakan itu memiliki ciri-ciri kudus, mandiri, dewasa, dinamis, berkembang dalam persaudaraan sejati dan menjadi garam serta terang dunia. Pemahaman ini didasarkan pada kebutuhan umat yang dicantumkan dalam visi paroki. Visi paroki adalah konkretisasi dari visi Keuskupan yang mendambakan semakin tegaknya kehadiran Kerajaan Allah di wilayah Keuskupan Purwokerto.

\subsection{Pertemuan APP Lingkungan Sebagai Dasar Membangun Visi Paroki}

Pertemuan APP Lingkungan adalah saat yang tepat untuk melihat bagaimana communio itu dicapai dalam perkembangan PKKR sampai saat ini. Lingkungan merupakan komunitas basis dengan lingkup teritorial. Pengelompokan dalam basis dan blok ini dimaksudkan untuk meningkatkan kesempatan saling mengenal dan memahami sesama anggota lingkungannya. ${ }^{10}$ Demikian pula pertemuan APP merupakan salah satu usaha PKKR membangun communio tersebut. Tujuan akhir dari APP, seperti yang diungkapkan oleh LPPS adalah untuk "membangkitkan kesadaran umat akan pentingnya pembaruan diri dan masyarakatnya dalam membangun manusia Indonesia yang dicita-citakan." "11 Dengan begitu Gereja mampu menyampaikan warta keselamatan yang sudah diterimanya. ${ }^{12}$ Maka, APP selaras dengan communio yang dicita-citakan PKKR.

Pertama, melalui pertobatan dan pembaruan hidup yang dilaksanakan dengan menggulati tema-tema bahan pertemuan APP, umat diajak untuk mengusahakan kekudusannya. Kedua, pertobatan dan pembaruan diri senantiasa mengasah kepekaan seorang kristiani untuk melihat tanda-tanda zaman melalui pengalam hidupnya. Ketiga, pertobatan bukanlah sesuatu yang dipaksakan melainkan muncul dari dalam dirinya. Keempat, pertemuan APP Prapaskah ini menjadi sarana keterlibatan umat beriman dalam hidup menggereja terutama di lingkungannya. Keterlibatan itu bukan hanya kehadiran saja melainkan juga sampai pada kesediaan untuk berperan aktif atau kesediaan menjadi fasilitator pertemuan. Kelima, pertemuan ini bisa menjadi sarana untuk membangun persaudaraan antar pribadi dalam satu lingkungan demi berkembangnya persaudaraan sejati. Dan $k e$ enam, pertemuan APP ini menjadi sarana umat lingkungan menjadi terang dan garam bagi masyarakat. Ia menjadi garam karena ia menjadi semakin "asin" melalui pertobatan dan pemurnian dirinya.

\subsection{Makna Commnuio}

Istilah communio berkaitan dengan kata koinônia yang berasal dari bahasa Yunani. Meski begitu nuansa dan arti yang dihasilkan tidaklah sama begitu saja. Sesuatu disebut com-munis bila ia berbagi dalam pekerjaan atau berbagi dengan seluruh orang. Demikian pula dalam bahasa Latin klasik, communio sebagai kata benda berarti membagikan, berbagi kepemilikan, karakteristik umum dan kadang-kadang komunitas. ${ }^{13}$ Communio dihubungkan dengan gerak Allah yang secara terus menerus communicates (berbagi, membagikan diri) kepada Gereja melalui sabda, pelayanan, sakramen dan Ekaristi) dan umat pun dipanggil bersatu dalam communicate satu sama lain, terutama melalui bantuan material. Dalam communion, segala buah-buah Ekaristi terpenuhi. ${ }^{14}$ Dalam konteks kristiani, communion diartikan sebagai relasi antara beberapa individu kristiani atau komunitas-komunitas kristiani yang dihasilkan dari partisipasi umum dalam sebuah realitas yang satu dan sama. ${ }^{15}$

Sedangkan kata koinonia merupakan bahasa Yunani kolvwvía. Kata ini awalnya bernada profan karena ingin mengungkapkan situasi sifat sosial dari manusia, dengan makna persahabatan, asosiasi, maupun idealisasi politis. Selanjutnya Angelo juga mengatakan bahwa istilah ini dipakai Gereja dalam konteks religius mulai awal abad I 
oleh para Bapa-bapa Gereja, yang memiliki tiga segi yaitu bersama dengan Trinitas, antara Allah dan manusia dan hubungan antar manusia. ${ }^{16} \mathrm{Nada}$ yang sama juga disampaikan oleh Paulus, namun lebih menekankan kristosentrisnya, bukan hanya dalam hal persekutuan atau komunitas. ${ }^{17}$ Dalam tulisan Paulus dan Yohanes, kata koinônia muncul lebih untuk mengungkapan keseluruhan isi atau yang ingin ditampakkan/ diungkapkan dari communio. ${ }^{18}$

\subsection{Melalui Pertemuan APP, PKKR Membangun Communio Internal dan Eksternal}

APP pada dasarnya menjadi usaha Gereja untuk terlibat dalam dunia untuk membangun Kerajaan Allah. Komunitas masyarakat dunia adalah kenyataan hidup yang ditinggali Gereja. Gereja diharapkan mengambil bagian dalam membawa perubahan hidup menuju manusia seutuhnya dan kesejahteraan umum sebagai tanda kehadiran Kerajaan Allah. Inilah communio eksternal yang ingin dibangun Gereja, seperti dalam Gaudium et Spes art. 1, Gereja wajib untuk ikut serta dalam kegembiraan dan kecemasan dunia sebagai sebuah komunitas eksternal.

Untuk dapat menjawab perutusan tersebut, PKKR sebagai sebuah komunitas lokal, juga menyusun beberapa langkah yang mengalir dari idealisasi yang tercantum dalam visinya. Visi tentang bentuk komunitas atau persekutuan itu menunjukkan niat perhatian PKKR dalam berperan di komunitas eksternal. Pemahaman dan penghayatan jati diri ini dimaksudkan dengan mengembangkan komunitas internal yaitu komunitas PKKR. Pertemuan APP tidak hanya mengajak orang untuk terlibat dalam komunitas masyarakat namun juga menemukan kehendak Allah dalam komunitas paroki maupun lingkungan. Pertemuan APP diharapkan oleh PKKR mampu membangun kekudusan, kemandirian dan kedewasaan dalam diri pribadi maupun komunitas warganya. Diharapkan Pertemuan APP mampu membangun persaudaraan dan solidaritas di antara komunitas lingkungan dan paroki. Dengan kata lain, untuk menghadirkan Kerajaan Allah, Gereja perlu mengalami Kerajaan Allah itu.

\subsection{Communio Selalu Bersemangatkan Koinônia (Relasi-Partisipasi yang Mendalam)}

Communio dan koinônia tidak bisa dipisahkan satu sama lain untul memahami arti Gereja. Communio atau koinônia bukan menjelaskan atau menggantikan istilah Gereja. Communio atau koinônia tidak sama dengan Gereja. Communio dan koinônia merupakan salah satu unsur penting dalam memahami esensi Gereja. Kesatuan (communio) itu senantiasa diperlengkapi maknanya dengan koinônia. Kesatuan dari beberapa orang itu diberi makna dengan adanya semangat untuk saling berbagi dengan sesama kelompok itu. Dalam kesatuan itu, masing-masing anggota membagikan diri bagi yang lain. Ia menjadi bagian dari yang lain. Bersama-sama orang lain ia berbagi diri.

Communio-koinônia itu dapat dipahami dengan berdasar pada misteri inkarnasi, gambaran Gereja sebagai Tubuh Mistik Kristus dan Gereja sebagai communion of communities. Misteri inkarnasi merupakan sebuah gerak communiokoinônia Allah kepada manusia. Allah berbagi diri dengan manusia melalui Yesus Kristus, Allah Putera yang menjadi manusia. Allah ingin bersatu dengan manusia dengan mengambil kemanusiaan. Dengan begitu manusia bisa masuk ke dalam keilahian kasih Trinitaris. Kesatuan komunitas diwujudkan dengan pemberian diri satu sama lain oleh para anggotanya. Gereja sebagai Tubuh Kristus lebih menunjukkan bahwa communio-koinônia merupakan kesatuan Gereja dengan Kristus dan kesatuan di antara umat beriman itu sendiri. Kesatuan dengan Kristus itu menghidupkan Gereja sehingga Gereja mampu berbuah dan berkembang. Dengan kata lain, Gereja tidak dapat dipisahkan dari Kristus. Kristus sebagai kepala tubuh mempersatukan anggota-anggota tubuh-Nya. Dalam Tubuh Kristus tetap ada diversivitas, pluralitas, dan kemajemukan yang memperkaya tubuh itu. Aneka peran dan karunia yang berbeda adalah demi kekayaan dan perkembangan Gereja. Dan sebagai tubuh, masing-masing anggota saling membutuhkan satu sama lain, saling membantu dan melindungi yang lain. Communio-koinônia itu dapat diselami melalui sejarah pergulatan Gereja yang sejak awal terdiri dari beberapa Gereja-Gereja lokal. Setiap komunitas Gereja lokal bersatu di dalam kesatuannya dengan uskup dan ekaristi yang satu. Gereja kemudian menjadi 
communion of local communities. Mereka diikat oleh Kristus yang satu dan sama. Persatuan atau communion of local communities itu juga diungkapkan melalui tanda yang nyata, entah melalui persekutuan dalam doa, kesaksian iman, pelayanan, maupun pewartaan.

\subsection{Melalui Kelompok/Paguyuban Itulah Communio-Koinônia yang Diharapkan PKKR Memperoleh Ungkapannya}

Seperti yang dialami PKKR, communiokoinônia itu dihayati di dalam hidup sebagai sebuah paroki, sebuah komunitas umat beriman yang "lebih lokal". Paroki merupakan bagian dari Gereja lokal yang bertempat di daerah tertentu dengan teritorial terbatas. PKKR mendefinisikan paroki sebagai persekutuan paguyuban-paguyuban umat beriman sebagai bagian dari keuskupan dalam batas-batas teritorial tertentu yang dipercayakan kepada Pastor Paroki. ${ }^{19}$ Kembali dipakailah kata "persekutuan paguyuban-paguyuban" untuk mendefinisikan paroki. Di dalam paroki masih terdapat paguyuban-paguyuban, entah kategorial maupun teritorial. Kategorial itu bisa berupa kelompok-kelompok doa, atau berdasarkan usia, minat, maupun pelayanan. Sedangkan teritorial adalah berupa lingkungan-lingkungan. Lingkungan merupakan paguyuban umat beriman yang bersekutu berdasarkan kedekatan tempat tinggal yang diatur dan ditetapkan oleh Dewan Pastoral Paroki. ${ }^{20}$ Lingkungan ini menjadi sebuah komunitas umat beriman PKKR yang kecil, teritorial tidak terlalu luas, dekat secara fisik dan lebih mudah untuk berkumpul. Setiap pribadi lebih dapat berperan dalam lingkunganlingkungan. Seperti halnya jemaat Gereja lokal pada zaman Gereja Perdana, mereka dapat dengan lebih mudah mengenal satu sama lain, berbagi perhatian, dan mudah untuk berkumpul untuk memecah roti. Semakin kecil komunitas itu, relasi antar anggota semakin besar. Maka dalam lingkungan-lingkungan, itu umat dapat mengungkapkan/ mewujudkan communiokoinônia dalam Gereja dengan lebih konkret dan mengena. Dengan lingkungan yang berjumlah umat terbatas, PKKR berharap agar setiap pribadi dapat memberikan peran sertanya dengan lebih banyak. Komunikasi dalam iman diharapkan akan menjadi lebih lancar saat komunitas menjadi lebih kecil. Lingkungan-lingkungan itu pun tidak berdiri sendiri, melainkan saling berjalinan satu sama lain. Di satu sisi ada kemandirian pada masing-masing lingkungan, di sisi lain, ada kerjasama antar lingkungan karena mau tak mau, paroki juga adalah communio dari lingkunganlingkungan.

\section{HASIL PENELITIAN DAN PEMBAHASAN}

\subsection{Analisis Data}

Secara teoritis, Pertemuan APP lingkungan di PKKR belum sepenuhnya membantu umat dalam membangun communio-koinonia yang dicitacitakan PKKR. Pertemuan APP Lingkungan ini belum seluruhnya menyentuh keenam dimensi communio-koinonia yang ada dalam visi PKKR 2008-2017. Padahal Pertemuan APP Lingkungan ini menjadi salah satu sarana yang digunakan masing-masing lingkungan untuk mengumpulkan warganya atau menjadikannya sebagai agenda rutin setiap tahun.

Kemandirian lingkungan sebagai sebuah komunitas sudah tampak dalam pertemuan APP. Hanya saja kemandirian itu lebih banyak dilihat dalam tataran praktis terutama oleh responden diploma. Padahal kemandirian juga perlu dilihat dari segi kemampuan komunitas lingkungan mengembangkan kreativitas dan inisiatif.

Dalam membangun persekutuan yang kudus, para responden sebagian besar menyadari pentingnya Perayaan Ekaristi pada hari Minggu dan kehidupan doa. Hanya saja kehidupan doa itu memiliki trend pada doa pribadi. Sedangkan doa komunal belum menjadi perhatian sebagian besar umat. Hal ini tampak nyata pada responden sarjana dan mereka yang pra SLTA. Komunitas belum dipahami sebagai sarana membangun kekudusan, seolah kekudusan merupakan urusan pribadi. Tingkat pendidikan tidak begitu saja membantu memahami hal ini. Maka pemahaman akan konsep kekudusan itu, perlu dibangun juga dalam tataran afektif.

Pertemuan APP hendaknya menunjang kedua sisi kedewasaan iman umat yaitu sisi spiritual dan kognitif para pesertanya. Artinya selain memberi inspirasi bagi hidup rohaninya, pertemuan APP juga menambah wawasan iman atau pengetahuan mengenai iman. Realitas yang perlu mendapat perhatian adalah mereka yang belum tamat SLTA di mana mereka mengalami ketimpangan antara hidup beriman secara pribadi, komuniter maupun dalam masyarakat. 
Kedinamisan lingkungan dilihat dari dua hal. Pertama, dari segi kegiatan. Dalam hal kegiatan, ternyata lingkungan juga memiliki kegiatan masing-masing selain Perayaan Ekaristi di lingkungan. Umat memiliki kesempatan untuk bertemu/ kegiatan dalam lingkungan. Paling tidak para peserta APP sebagian besar memiliki kegiatan ini. Namun dari segi yang kedua, yaitu pesertanya, muncul kesulitan besar untuk mengadakan pertemuan APP berupa kesibukan kerja/ tugas di sekolah. Hal ini paling dirasakan oleh mereka yang pra SLTA maupun yang SLTA. Maka dalam segi yang kedua, yaitu pribadi peserta, kedinamisan masih memiliki kendala.

Pertemuan APP Lingkungan membawa dampak positif bagi persaudaraan di lingkungan. Banyak yang merasakan bahwa pertemuan APP memiliki dampak membangun komunitas lingkungan. Hanya saja tidak seluruh dari mereka ini mengenal dan berelasi akrab dalam satu lingkungan. Mereka yang berpendidikan menengah perlu mendapat perhatian. Konsep bahwa komunitas hanya menjadi tempat pengembangan non rohani begitu kuat, sedangkan relasi tidak begitu penting.

Dalam menjadi terang dan garam bagi masyarakat, para responden tidak banyak yang memahami bahwa nilai-nilai kristiani perlu dihidupi di dalam seluruh segi hidupnya agar mereka mampu menggarami dan menerangi masyarakat dengan seluruh hidup mereka. Menjadi terang dan garam masih dilihat dalam lingkup sekitar rumah (relasi tetangga), padahal pekerjaan dan keluarga juga menjadi sarana menjadi terang dan garam bagi masyarakat. Hal ini paling dialami oleh responden berpendidikan menengah. Nampaknya status pendidikan mempengaruhi luas wilayah mereka dalam berelasi dengan masyarakat. Demikian pula pemahaman perutusan mereka sebagai sebuah komunitas yang hidup dalam komunitas.

\subsection{Keprihatinan yang Ditemukan}

\subsubsection{Usaha Mencapai Kekudusan adalah Urusan Pribadi}

Kekudusan disadari sebagai urusan pribadi. Komunitas belum disadari dapat membangun kekudusan itu. Kekudusan ditempatkan hanya pada kegiatan-kegiatan rohani pribadi masingmasing anggota lingkungan. Hal itu disadari sebagai urusan mereka pribadi dengan Allah.
Paguyuban disadari sebagai kelompok yang tidak jauh beda dengan kelompok atau komunitas di dalam pergaulan masyarakat mereka masingmasing. Demikian pula komunitas belum memberi pengaruh pada kehidupan spiritual masing-masing pribadi. PKKR cenderung mementingkan segi-segi praktis dari sebuah paguyuban. Komunitas dipahami sebagai wadah pertemuan untuk hal-hal selain yang dianggap wilayah pribadi yang dalam arti tertentu relasi pribadi dengan Allah. Bahkan solidaritas yang sebenarnya menjadi gerakan komunitas juga dipersempit menjadi gerakan pribadi. Padahal solidaritas akan mendapat kekuatannya bila menjadi sebuah gerakan sosial atau komuniter.

\subsubsection{Kurangnya Semangat "Berbagi" Paguyuban/Komunitas Lingkungan}

Unsur koinonia dalam lingkungan di PKKR menjadi berkurang karena tidak setiap anggotanya rela berbagi dengan anggota lainnya atau dengan komunitasnya. Kerelaan berbagi itu dalam bentuk berbagi waktu dan perhatian. Komunitas dipandang dari segi praktis atau yang kelihatan, misal jumlah, kegiatan, penyajian acara, dan sebagainya. Keterlibatan mereka masih pada halhal praktis. Paguyuban dirasakan sebagai sebuah kelompok secara administratif. Sebab lainnya adalah kecenderungan untuk mengharapkan sesuatu dari komunitas. Kecenderungan ini tidak terimbangi oleh semangat memberi (berbagi). Kurang luasnya pengenalan (relasi) mereka, dapat disebabkan oleh tingkat pendidikan dan dominasi tingkat pendidikan lain. Selain itu, cara berelasi masing-masing orang juga berbeda. Pertemuan APP juga belum efektif di dalam membangun paguyuban.

\subsubsection{Tidak Seluruh Medan Perwujudan Iman Tergarap dengan Baik}

Iman belum menjadi penggerak umat PKKR dalam menjadi garam dan terang masyarakat. Iman lebih digarap dalam tataran pribadi masingmasing warga. Hal ini selaras dengan solidaritas yang juga dalam tataran pribadi pula. Sedangkan pertemuan lingkungan terutama APP belum menggerakkan sepenuhnya semangat solidaritas umat. Paling tidak ada lima medan perwujudan iman kristiani. Medan itu antara lain pribadi, keluarga, pekerjaan, relasi dengan tetangga dan masyarakat. Kelima medan itu mencakup 
tiga segi dalam membangun communio melalui pertemuan APP yaitu pribadi, paguyuban dan masyarakat. Akan tetapi sebagian besar peserta pertemuan APP belum menyadari atau mengalami bahwa perwujudan iman mencakup kelima medan itu atau ketiga segi sekaligus. Kurangnya medan perwujudan iman yang tergarap bisa terjadi karena kurangnya relasi dan pemahaman akan medan-medan perwujudan iman, terutama oleh mereka yang berpendidikan menengah. Pertemuan APP lebih banyak menyentuh pada kehidupan pribadi dan hanya sedikit yang kemudian terdorong untuk terlibat dalam masyarakat dengan mengikuti kegiatan di masyarakat. Pertemuan APP lebih banyak mendorong pesertanya dalam bidang pribadi saja. Pertemuan APP sebagai salah satu pertemuan lingkungan dan sarana/ kesempatan membangun communio, ternyata masih belum mampu sepenuhnya membawa para peserta memahami berbagai medan perwujudan imannya.

\subsection{Berbagai Kekuatan Dan Peluang Yang Sudah Dimiliki}

\subsubsection{Potensi Pribadi Warga Lingkungan}

Dalam segi pribadi, PKKR memiliki beberapa kekuatan pastoral. Pertama, sebagian besar peserta pertemuan APP selalu mengikuti Perayaan Ekaristi mingguan. Kedua, sebagian besar peserta memiliki kegiatan doa selain perayaan Ekaristi. Ketiga, Perayaan Ekaristi sudah mampu membantu umat beriman PKKR dalam mengolah hidup doa dan relasi dengan Allah. Keempat, PKKR memiliki cukup tenaga untuk mensosialisasikan penggunaan dana APP. Selain dan dari kekuatan itu muncul peluang. Pertama, pertemuan APP berpengaruh positif terhadap frekuensi kehadiran umat dalam Perayaan Ekaristi. Kedua, informasi penggunaan dana APP didapat dalam pertemuan APP.

\subsubsection{Memiliki Sense of Community}

Dalam segi paguyuban atau komunitas lingkungan, PKKR memiliki beberapa kekuatan pastoral. Pertama, kemandirian sudah dirasakan dan dialami oleh sebagian besar peserta pertemuan APP. Kedua, sebagian besar peserta pertemuan APP memiliki dan mengikuti kegiatan lingkungan non-Ekaristi. Ketiga, sebagian besar responden mengenal sebagian besar warga lingkungannya. Keempat, pertemuan APP berdampak positif bagi paguyuban. Kelima, hampir seluruh pengurus lingkungan, anggota DPP dan pengurus kelompok kategorial usia mengenal seluruh umat lingkungan.

Selain kekuatan di atas ada pula beberapa peluang yang bisa digunakan untuk memaksimalkan kekuatan tersebut. Pertama, ketertarikan atau kebutuhan mereka untuk hadir dalam kegiatan lingkungan ternyata cukup besar. Kedua, responden Tionghoa yang tidak begitu banyak mengenal warga lingkungannya, ternyata lebih menyukai kegiatan lingkungan non-rohani. Ketiga, kegiatan lingkungan non-Ekaristi yang paling diminati adalah kegiatan lingkungan non rohani. Keempat, responden purnakarya dapat menjadi contoh dan referensi dalam pengenalan warga lingkungan. Kelima, pertemuan APP mampu menjadi sarana membangun persaudaraan paguyuban lingkungan.

\subsubsection{Keterbukaan dalam Memanfaatkan Berbagai Medan Perjumpaan}

PKKR memiliki modal yang cukup untuk mewujudkan iman kristiani dalam berbagai aspek kehidupan. Hubungan antar agama di tempat para peserta pertemuan APP tinggal dapat dikatakan baik. Hampir seluruh responden mengatakan bahwa relasi dengan umat beragama lain di masyarakatnya berjalan baik. Selain kekuatan-kekuatan itu, ada pula peluang yang berharga bila dilewatkan begitu saja. Pertama, pengenalan terhadap warga RT (Rukun Tetangga) atau orang yang tinggal dalam satu kawasan bersama menjadi sebuah jalan masuk ke dalam kehidupan bersama masyarakat. Kedua, kegiatan lingkungan dapat menjadi pendukung kesadaran akan berbagai medan perwujudan iman. Ketiga, responden Jawa sebenarnya bisa menjadi pelopor dan perintis dalam hal pengenalan itu. Hal itu disebabkan oleh karena mereka ini sebagian besar mengenal warga tetangga RT tempat tinggalnya.

\subsection{Usulan Langkah Pastoral}

\subsubsection{Perayaan Liturgi yang Mengembangkan Paguyuban}

Perayaan Ekaristi memiliki dimensi eklesiologis. Ekaristi merupakan perayaan seluruh Gereja karena menghadirkan siapa Gereja dan mempersatukan yang ada di dalam perayaan 
itu sebagai Gereja (SC art. 48). Kesatuan dan keterlibatan itu menjadi ciri utama dalam Ekaristi. Demikian pula Ekaristi yang diadakan lingkungan. Dengan demikian kata kebersamaan dan keterlibatan menjadi kata kunci memahami Perayaan Ekaristi dalam lingkungan. Untuk itulah para peserta dan juga seluruh umat di lingkungan perlu diberi pemahaman sampai pada hal itu. Pemahaman itu dapat diberikan dalam pertemuan tertentu di lingkungan dan juga di dalam kesempatan lain (seminar, homili, lembaran berita paroki, dan sebagainya). Untuk keterlibatan dalam Ekaristi, dapat ditempuh cara dengan membuat Ekaristi yang melibatkan sebanyak mungkin umat yang hadir. Cara ini dapat berupa dengan menambah frekuensi perayaan Ekaristi dalam lingkungan. Selain itu, kaum muda juga perlu dilibatkan lebih banyak dalam Ekaristi. Dengan demikian mereka memiliki kesempatan menghayati dimensi paguyuban dalam Ekaristi. Diharapkan mereka terdampingi dengan masuk ke dalam komunitaskomunitas yang ada. ${ }^{21}$ Maka salah satu sarana keterlibatan mereka dalam membangun komunitas setempat adalah dengan Ekaristi ini. Cara lain adalah dengan mengadakan perayaan Ekaristi dalam blok-blok. Blok adalah bagianbagian dari lingkungan yang jumlahnya tidak terlalu banyak. Kecilnya lingkup blok ini akan membuat setiap orang lebih mudah menyadari dan mengaktualisasikan keterlibatannya dalam Ekaristi.

\subsubsection{Memunculkan Kelompok Minat Kegiatan Rohani Dan Rekreatif}

Komunitas seringkali dilupakan sebagai medan pengembangan iman umat PKKR terutama mereka yang berpendidikan menengah. Untuk itu, perlulah ada perubahan paradigma dalam komunitas lingkungan mengenai peran komunitas dalam hidup relasi umat dengan Allah yang sudah terjalin pula dalam Ekaristi. Paradigma tersebut dapat dirangsang dengan mengadakan berbagai kegiatan pengembangan iman dalam komunitas. Artinya komunitas lingkungan menyediakan sarana dan kesempatan bagi umat untuk mengembangkan hidup beriman mereka.

\subsubsection{Mengembangkan Sinergisitas Lingkungan dan Kelompok Kategorial}

Komunitas mandiri yang dimaksudkan PKKR adalah komunitas yang mampu memiliki kekuatan membangun persaudaraan yang lebih luas dengan komunitas yang lebih besar maupun dengan komunitas lain. Inilah yang dimaksud sebagai sinergisitas bagian-bagian Gereja. Setiap kelompok/ komunitas diharapkan memiliki roh yang sama dalam bergerak dan beraktivitas. Dalam kemandirian, setiap komunitas bersentuhan dan berelasi dengan kelompok lain. Kerjasama inilah yang akan memberi banyak kesempatan umat untuk bersosialisasi dan sekaligus memanfaatkan berbagai medan perjumpaan iman. Dengan demikian modal sosialitas yang cukup ini mampu membangun jejaring antar lingkungan maupun dengan kelompok-kelompok kategorial lainnya.

\subsubsection{Pemberdayaan Kerasulan Awam Melalui Lingkungan}

Kaum awam memiliki sebuah kekhasan (hidup di tengah masyarakat dan urusan-urusan duniawi) dalam karya kerasulan mereka dalam ikut serta mengemban tugas imamat, kenabian dan rajawi Kristus serta mengambil bagian dalam perutusan segenap Umat Allah dalam Gereja dan dunia. ${ }^{22}$ Merekalah yang nantinya direkomendasikan MUSPAS untuk meningkatkan dialog dan kerjasama dengan berbagai pihak seperti halnya dalam visi keuskupan yang juga mengajak kerjasama dengan pihak-pihak yang berkehendak baik. ${ }^{23}$

Sebagian besar umat sudah mengenal sebagian besar warga masyarakat di lingkungan tempat tinggalnya. Hanya saja yang masih kurang adalah koordinasi dan sarana untuk memanfaatkan peluang itu. Koordinasi itu dapat diatasi dengan adanya pendampingan para pelayan publik.

\subsubsection{Membangun Paguyuban yang Efektif dengan Memecah Lingkungan Besar dan Membuat Blok Lingkungan}

Lokalitas Gereja terletak pada pemahaman jatidiri Gereja dalam situasi dan tempat tertentu. Lokalitas berawal dari suatu keragaman. Universalitas Gereja tidak menghapuskan adanya keragaman di dalam Gereja. Bahkan justru 
keragaman itu memperkaya Gereja. ${ }^{24}$ Semakin kecil komunitas, perjumpaan dengan masyarakat akan semakin mendalam karena fokus permasalahan dan perjumpaan semakin seragam. Maka agar komunitas lingkungan itu semakin efektif dalam menghayati lokalitas penghayatan imannya, luas dan jumlah perlu dibatasi/ diperkecil. Peranan blok dalam membangun suasana paguyuban akan menjadi lebih terasa saat masing-masing blok diberi kesempatan oleh paroki maupun lingkungan. Sebenarnya dengan adanya blok wilayah itu sudah dapat sedikit demi sedikit kendala waktu diatasi. Dengan sedikitnya orang, kesepakatan waktu lebih mudah dicapai.

\subsubsection{Optimalisasi Pertemuan APP melalui Kelompok-Kelompok Khas/Minat/ Kategorial}

Ada tiga hal yang menjadi unsur penting dalam APP, yang dapat menjadi jalan masuk untuk mengoptimalisasi pertemuan tersebut. Tiga hal itu adalah kebersamaan, rekonsiliasi dan usaha membangun dunia baru. ${ }^{25}$ Pertemuan APP hendaknya mampu menyentuh dan sampai pada ketiga hal tersebut. Para peserta pertemuan APP dan juga umat yang lain perlu memahami dengan benar dan lengkap mengenai seluk beluk APP dan juga pertemuan yang diadakan. Selain itu, pertemuan APP perlu dipahami baik dari segi tujuannya, isinya dan follow up dari pertemuan itu. Pertama, sosialisasi pertemuan perlu diadakan secara menyeluruh. Kedua, isi dan metode penyajian perlu ditinjau lagi. Ketiga, perlu ada follow up yang jelas dalam pertemuan APP. Dan tak kalah pentingnya, pertemuan APP di Lingkungan akan menjadi lebih menyentuh dan efektif saat dilakukan dalam kelompok kecil maupun kelompok kategorial atau minat yang lain.

\section{PENUTUP}

\subsection{Kesimpulan}

Nampaknya dalam menanggapi masalah yang ada, PKKR perlu mensinergikan setiap Tim Kerja dan juga bidang yang terkait agar solusi pastoral dapat teratasi. Demikian pula setiap peluang kegiatan dan sarana (semisal lingkungan, kelompok minat, maupun kelompok kategorial) perlu dimanfaatkan semaksimal mungkin.
Ketidakmaksimalan gerak sebuah kelompok/ komunitas dapat memberi pengaruh negatif kepada kelompok yang lain. Masing-masing unsur visi sebenarnya mengandaikan kerjasama dan sinergitas masing-masing unsur dalam DPP dan kelompok-kelompok kategorial (baik usia maupun liturgi) untuk bekerja sama dalam merencanakan dan melaksanakan kegiatan. Tentu hal ini dapat berjalan bila ada grand design atau rencana jangka panjang paroki yang menjadi pedoman masing-masing bidang atau kelompok kategorial itu.

\subsection{Saran}

Untuk itu ada beberapa hal yang perlu diperhatikan dalam menggulati visi tersebut.

1. Sinergitas antar komunitas. Komunitas yang cukup banyak di PKKR mengandung sebuah kekuatan yang sangat potensial. Hanya saja perlu ada kerjasama dan kesinambungan antar kelompok tersebut, teritorial maupun kategorial. Modal awal untuk sinergitas adalah penemuan jati diri (kekhasan) masingmasing komunitas.

2. Dewan Pastoral Paroki hendaknya memiliki sebuah program yang saling berkaitan antar bidang.

3. Pastor paroki sebagai pimpinan managerial paroki hendaknya menjadi penjaga arah visi paroki. Dengan demikian dapat diupayakan beberapa hal yang perlu bila ada kekurangan gerakan visi tersebut.

4. Bagi Tim Penyusun Bahan Pertemuan APP, ada banyak komunitas dengan berbagai situasi dan keragaman karakter peserta pertemuan APP. Maka perlu ada perjumpaan dengan berbagai lini dan komunitas untuk menjaring keprihatinan dan kebutuhan apa yang ingin digulati oleh masing-masing komunitas.

5. Para pengurus Lingkungan perlu membuka diri dalam mengembangkan Lingkungannya sehingga ada kesempatan untuk mengolah jatidiri komunitas lingkungan sekaligus memperdalam jati diri itu saat berjumpa dengan komunitas lainnya.

6. Perlu adanya sosialisasi berkelanjutan mengenai visi paroki yang juga telah dijabarkan secara sistematis dalam Arah Karya Pastoral PKKR. 


\section{Dhimas Martin Yuniar}

Rohaniwan dan Pemimpin Jemaat di Paroki Purbalingga; Alumnus Program Magister Teologi Universitas Sanata Dharma:ferrerius@ yahoo.com

\section{CATATAN AKHIR}

1 Y. Congar,"Koinonia”, dalam A.D. Bernardino, Encyclopedia of the Early Church, I, James Clarke \& Co., 188.

2 G.S. Wakefield (ed), A Dictionary of Christian Spirituality, 241. Sharing in something with someone. Dengan berkonotasi pada fellowship, communion, participation dan sharing.

3 Sinclair B Ferguson, David F Wright (eds), New Dictionary of Theology, 372.

4 Konsili Vatikan II, Lumen Gentium, art. 11.

5 Y. Congar, "Koinonia”, 188.

6 Rumusan ini diambil dari bahan rapat Tim Kerja Visi Misi PKKR pada tanggal 22 Mei 2007.

7 Hasil Penelitian Tim Kerja Visi Misi PKKR pada tahun 2007. Hasil tersebut disampaikan dalam rapat Tim Kerja Visi Misi pada tanggal 7 Agustus 2007.

8 Paroki Katedral Kristus Raja Purwokerto, Arah Karya Pastoral PKKR Purwokerto Tahun 2008-2017, 14-15.

9 Di sisi lain, penelitian ini adalah penelitian sosial di mana yang menjadi objek penelitian adalah manusia. Manusia begitu kompleks dan tak dapat dikatakan sebagai homogen, terutama dalam tema penelitian semacam ini. Oleh karena itu, random simple sampling tidak dapat tepat digunakan.

10 Arah Karya Pastoral Paroki Katedral Kristus Raja Purwokerto Tahun 2008-2017, 23.

1 Caritas Indonesia-LPPS, Profil Program Aksi Puasa Pembangunan Nasional (APP Nasional), 2.

12 Konsili Vatikan II, Gaudium et Spes, art. 1.

13 J.M.R. Tillard, "Communion”, dalam J.Y. Lacoste (ed.), Encyclopedia of Christian Theology, 322. Something is com-munis that "shares the office" and, in a derivative sense, what is "shared among all," hence in common. This relationship of the term to the idea of a large number had the effect that sometimes it came to evoke banality, vulgarity, or even impurity*. In classical Latin the noun communio means sharing, shared ownership, common characteristics, and sometimes community (Ernout-Meillet 1951).

14 M.R. Tillard, "Communion", 322. These were derived from the fact that the community in question had its source in what God himself continually communicates to theChurch (Word*, ministry*, sacraments*, the most important of which is the Eucharist*) and what believersare called on to communicate to one another, particularly through mutual material assistance. There was communio in the goods communicated by God, and it embraced all the members of the body of Christ.
15 S.B. Ferguson-D.F Wright (eds.), The New Dictionary of Theology, 372. A relation between individual Christians or Christian communities resulting their common participation in one and the same reality.

16 A. di Bernardino, Encyclopedia of the Early Church, I, 467.

17 G.S. Wakefield (ed.), A Dictionary of Christian Spirituality, 241. Union of belivers with Christ, in Spirit, and hence among one another (Gal 2:9, Rom 11:17).

18 J.M.R. Tillard, Church of Churches: The Ecclesiology of Communion, 18.

19 Paroki Katedral Kristus Raja Purwokerto, Pedoman Pelaksanaan Dewan Pastoral Paroki Paroki Katedral Kristus Raja Purwokerto, 21.

20 Paroki Katedral Kristus Raja Purwokerto, Pedoman Pelaksanaan Dewan Pastoral Paroki Paroki Katedral Kristus Raja Purwokerto, 16.

21 Keuskupan Purwokerto, Musyawarah Pastoral Keuskupan Purwokerto 30 April-4 Mei 2001, 4.

22 Konsili Vatikan II, Apostolicam Actuositatem, art. 2. Sedangkan kaum awam ikut serta mengemban tugas imamat, kenabian dan rajawi Kristus, menunaikan bagian mereka dalam perutusan segenap Umat Allah dalam gereja dan di dunia.

23 Keuskupan Purwokerto, Gereja Keuskupan Purwokerto Menegaskan Arah 2006-2011, 44.

24 Konsili Vatikan II, Lumen Gentium art. 7.

25 Caritas Indonesia-LPPS, Profil Program Aksi Puasa Pembangunan Nasional (APP Nasional), 3.

\section{DAFTAR PUSTAKA}

Caritas Indonesia-LPPS, 1994. Profil Program Aksi Puasa Pembangunan Nasional (APP Nasional), Seri Forum LPPS No.27, LPPS, Jakarta

Congar, Y., 1992. "Koinonia", dalam A.D. Bernardino, Encyclopedia of the Early Church, I, James Clarke \& Co., Cambridge.

Ferguson, S.B.-D.F. Wright, 1988. New Dictionary of Theology, Intervarsity Press, England-Illinois.

Tillard, J.M.R., 1992. Church of Churches: The Ecclesiology of Communion, The Liturgical Press, Collegeville. 2005 "Communion", dalam J.Y. Lacoste (ed.), Encyclopedia of Christian Theology, Routledge, New York

Wakefield, G.S., 1983. A Dictionary of Christian Spirituality (ed), SCM Press Ltd., London. 
Arah Karya Pastoral Paroki Katedral Kristus Raja Purwokerto Tahun 2008-2017, PKKR, Purwokerto 2007.

Paroki Katedral Kristus Raja Purwokerto, Pedoman Pelaksanaan Dewan Pastoral Paroki Paroki Katedral Kristus Raja Purwokerto, Purwokerto, PKKR 2007.
Keuskupan Purwokerto, 2006. Gereja Keuskupan Purwokerto Menegaskan Arah 20062011, Purwokerto

Keuskupan Purwokerto, Musyawarah Pastoral Keuskupan Purwokerto 30 April-4 Mei 2001. 